\title{
Combined intermittent hypoxia and surface muscle electrostimulation as a method to increase peripheral blood progenitor cell concentration Ginés Viscor*1, Casimiro Javierre ${ }^{2}$, Teresa Pagès ${ }^{1}$, Josep-Lluis Ventura ${ }^{3}$, Antoni Ricart ${ }^{3}$, Gregorio Martin-Henao ${ }^{4}$, Carmen Azqueta ${ }^{4}$ and Ramon Segura ${ }^{2}$
}

Address: ${ }^{1}$ Departament de Fisiologia - Biologia, Universitat de Barcelona, Av. Diagonal, 645 E-08028 Barcelona, Spain, ${ }^{2}$ Departament de Ciències Fisiologiques II, Universitat de Barcelona, Feixa Llarga s/n, L'Hospitalet de Llobregat, Barcelona, Spain, ${ }^{3}$ Hospital Universitari de Bellvitge, Feixa Llarga s/n, L'Hospitalet de Llobregat, Barcelona, Spain and ${ }^{4}$ Centre de Transfusió i Banc de Teixits (CTBT), Unitat de Teràpia Cellular, Feixa Llarga s/n, L'Hospitalet de Llobregat, Barcelona, Spain

Email: Ginés Viscor* - gviscor@ub.edu; Casimiro Javierre - cjavierre@ub.edu; Teresa Pagès - tpages@ub.edu; JosepLluis Ventura -6775jvf@comb.cat; Antoni Ricart -8936ard@comb.cat; Gregorio Martin-Henao - gmartin@bstcat.net; Carmen Azqueta - cazqueta@bstcat.net; Ramon Segura - rasegura@ub.edu

* Corresponding author

Published: 29 October 2009

Journal of Translational Medicine 2009, 7:91 doi:10.1 I86/1479-5876-7-91
Received: II May 2009

Accepted: 29 October 2009

This article is available from: http://www.translational-medicine.com/content/7/I/91

(C) 2009 Viscor et al; licensee BioMed Central Ltd.

This is an Open Access article distributed under the terms of the Creative Commons Attribution License (http://creativecommons.org/licenses/by/2.0), which permits unrestricted use, distribution, and reproduction in any medium, provided the original work is properly cited.

\begin{abstract}
Background: Our goal was to determine whether short-term intermittent hypoxia exposure, at a level well tolerated by healthy humans and previously shown by our group to increase EPO and erythropoiesis, could mobilize hematopoietic stem cells (HSC) and increase their presence in peripheral circulation.
\end{abstract}

Methods: Four healthy male subjects were subjected to three different protocols: one with only a hypoxic stimulus $(\mathrm{OH})$, another with a hypoxic stimulus plus muscle electrostimulation (HME) and the third with only muscle electrostimulation (OME). Intermittent hypobaric hypoxia exposure consisted of only three sessions of three hours at barometric pressure $540 \mathrm{hPa}$ (equivalent to an altitude of $5000 \mathrm{~m}$ ) for three consecutive days, whereas muscular electrostimulation was performed in two separate periods of $25 \mathrm{~min}$ in each session. Blood samples were obtained from an antecubital vein on three consecutive days immediately before the experiment and $24 \mathrm{~h}, 48 \mathrm{~h}$, 4 days and 7 days after the last day of hypoxic exposure.

Results: There was a clear increase in the number of circulating CD34+ cells after combined hypobaric hypoxia and muscular electrostimulation. This response was not observed after the isolated application of the same stimuli.

Conclusion: Our results open a new application field for hypobaric systems as a way to increase efficiency in peripheral HSC collection. 


\section{Background}

Stem cells (SCs) are primitive cells with the potential to differentiate into mature cells [1]. An increase in SCs is observed after various events such as myocardial infarction [2], dilated myocardiopathy [3], cardiac surgery with cardiopulmonary bypass [4], twelve weeks of physical exercise [5,6], menstruation [7], cessation of smoking [8], and in animals or human cells subjected to deep hypoxia conditions in vitro [9-12].

Several studies have found that elevated concentrations of SCs correlate with better clinical outcomes [13], since they possess a general regenerative capacity in blood vessel disorders [14]. Various methods of SC delivery have been shown to be beneficial, mostly with autologous bone marrow cell transplantation [15-17]. No significant differences were found when bone marrow cells or SCs from peripheral blood were compared [18], nor when the comparison was made between bone marrow cells and adipose tissue-derived SCs [19].

An EPO-induced increase of hematopoietic stem cells (HSCs) has been detected in healthy individuals and in patients with renal anemia at two weeks post-administration [20]. Moreover, an EPO-induced mobilization and homing of HSCs and their mediated neovascularization has also been reported in rats after post-myocardial infarction heart failure after six weeks of treatment [21].

Historically, intermittent hypoxia exposure sessions have been used to improve the physical condition and to treat several illnesses, mostly in the countries of the former Soviet Union, although this has been done without a clear understanding of their holistic effects [22]. At all events, this practice has now become widespread in the sport world, and there are even several commercialized forms. Hypoxia exposure has been combined with normal athletic training according to different patterns [23], the most widely-adopted at present being the living-high traininglow model [24].

The different forms of standard physical exercise can be difficult to apply with hypoxic procedures, especially in some patients with severe obesity, osteoarticular conditions, neurological sequelae, etc. In contrast, muscle electrostimulation can be easier to apply and has been shown to be as efficient in mimetizing training effects [25-27]. However, intermittent hypobaric hypoxia exposure has been demonstrated to be an efficient stimulus for eliciting adaptive responses in myocardium [28] and skeletal muscle [29].

The aim of the present study was to determine whether it was possible to increase blood SC concentration by means of: 1) short-term intermittent hypoxia, at levels well tolerated by healthy humans and previously demonstrated by our group as being capable of increasing EPO and stimulate erythropoiesis [30] and 2) muscular electrostimulation alone or combined with the aforementioned hypoxia.

\section{Methods}

\section{Subjects and procedures}

Subjects were four healthy males, all members of the research group (AR, CJ, GV and JLV), without toxic habits or medication and with different levels of habitual physical activity (one jogger 4 days/week, one gym user, also 4 days/ week, and two without regular physical training). Their mean age was 54.3 (range 46-60), mean height $175 \mathrm{~cm}$ (range 170-182), and mean body mass $85.5 \mathrm{~kg}$ (range 7589). They were each subjected to three different protocols: one with only a hypoxic stimulus $(\mathrm{OH})$, another with a hypoxic stimulus plus muscle electrostimulation (HME) and the third with only muscle electrostimulation (OME) [see additional file 1]. In order to avoid undesired interactions, each experimental set was performed at least three months after the preceding one. A hypobaric hypoxia stimulus was applied in a computer-controlled hypobaric chamber [see additional file 2] (CHEx-1; Moelco, Spain) for $3 \mathrm{~h}$ on three consecutive days, always from 5 to $8 \mathrm{a} . \mathrm{m}$. (subjects having spent the previous week following the habitual diet and physical activity and with no detected illnesses or chronobiologic changes); the simulated altitude was $5000 \mathrm{~m}(400 \mathrm{mmHg}=533 \mathrm{hPa})$, reached in $10 \mathrm{~min}$ and returning to sea level pressure in $15 \mathrm{~min}$.

Muscle electrostimulation was applied by means of a Winform Stimulation System (Model W5 multi frequency training, Winform S.r.l., Venice, Italy) according to a widely accepted procedure and following previously described general characteristics [31]. Surface electrodes were fixed on both knee extensors and abdominal wall muscles. Stimulation was achieved at the maximal tolerated intensity (regulated individually by each experimental subject) during two periods of $25 \mathrm{~min}$, one in the firsthalf period of hypobaric chamber stay (90 $\mathrm{min}$ ) and the other in the second 90-min period of stay. The protocol of OME was the same as HME and also took place into the hypobaric chamber; however, as the door was open there was no hypoxic stimulus. Oxygen arterial saturation was measured at rest during each hypoxia exposure session by means of a pulsioxymeter (Onyx II 9550, Nonin Medical Inc., Plymouth, MN). The study was conducted according to the Helsinki Declaration and the experimental protocol was approved by the institutional ethics committee.

\section{Blood sampling, CD34 staining and flow cytometry assay} In order to detect possible individual oscillations, baseline blood samples were drawn on each of the three days prior to the first experiment $(\mathrm{OH})$. Subsequently, blood samples were always obtained just before each of the experimental sets (OH, HME and OME) and $24 \mathrm{~h}, 48 \mathrm{~h}, 4$ 
and 7 days later. In the third protocol (OME) an additional sample was taken 10 days after the end of muscular electrostimulation. All samples were obtained between 6 and 8 a.m. following the same extraction methodology as detailed below. Samples were preserved, without any previous processing, at a temperature between 4 and $6{ }^{\circ} \mathrm{C}$ until transfer to the hematology laboratory. There they were processed according to a blinded design (the technicians involved had no knowledge of either the experimental subject or the protocol).

Peripheral blood samples were collected by puncture of an antecubital vein and placed in tubes treated with 0.34 $\mathrm{M}$ di-potassium ethylenediaminetetraacetic acid anticoagulant. All samples were stored at a temperature of $4{ }^{\circ} \mathrm{C}$ and processed within $24 \mathrm{~h}$ of arrival at the laboratory. Blood cell count was assessed by use of an automatic cell counter (AcT-diff; Beckman Coulter, Miami, FL). Samples were incubated for cytometric absolute count with anti-human fluorescein isothiocyanate (FITC)-conjugated CD45 monoclonal antibody (Beckman Coulter, clone J.33) and antihuman phycoerythrin (PE)-conjugated anti-CD34 (clone 8G12, Becton Dickinson) in PBS containing 1\% albumin and $0.1 \%$ sodium azide for $15 \mathrm{~min}$ at room temperature. Red blood cells were lysed with $1 \mathrm{ml}$ of quick lysis solution (CYT-QL-1, Cytognos) for $15 \mathrm{~min}$ at room temperature. Samples were incubated under dark conditions and analyzed immediately. To ensure accuracy, reverse pipetting was used to dispense the volumes.

A single-platform protocol with Perfect-Count microspheres CYT-PCM-50 (Cytognos, Salamanca, Spain) was used according to manufacturer's instructions. The Perfect-Count microspheres system contains two different fluorospheres in a known proportion (A and B beads), thus assuring the accuracy of the assay by verifying the proportion of both types of beads. Known volumes $(25$ $\mu \mathrm{l})$ of Perfect-Count Microspheres were added to the same known volume $(25 \mu \mathrm{l})$ of stained blood in a lyse-no-wash technique, and the beads were counted along with the cells. Cell viability was measured by staining the samples with the vital dye 7-aminoactinomycin D (7-AAD), as proposed by the ISHAGE guidelines [32]. Samples were analyzed on a FACScan Scalibur flow cytometer (BD Biosciences) with a 488-nm argon laser and Cell Quest 3.1 software (BD Biosciences). The instrument was aligned and calibrated daily using a three-color mixture of Calibrite $^{\mathrm{TM}}$ beads (BD Biosciences) with FACSComp software (BD Biosciences). The gating strategy followed also ISHAGE guidelines [32].

\section{Statistical analyses}

The non-parametric Friedman test for repeated measures was used. All tests were performed using SPSS v.14. Statistical significance was set at $\mathrm{P}<0.05$. Values are expressed as the median value \pm standard deviation (SD).

\section{Results}

Only the HME experimental data set showed a clear increase for all the subjects (about $3 \times$ fold) in the percentage of circulating $\mathrm{CD} 34^{+}$cells, although no significant differences were detected $(p=0.056)$. However, the number of circulating CD34+ cells increased in this experiment from a median value of 0.95 cells $\cdot \mu \mathrm{L}^{-1}$ (range: $0.5-2.1$ ) to reach a median level of 6.65 cells $\cdot \mu \mathrm{L}^{-1}$ (range: 3.7-10.7), this increase being clearly significant $(\mathrm{p}=0.009)$ (Figure $1)$.

No other studied parameter showed changes in this experimental block. Furthermore, neither OH nor OME experimental data showed statistically significant changes across the study for general leukocyte parameters or circulating CD34+ cells (Table 1).

\section{Discussion}

The main result of the present study is the synergic capacity of a short-term intermittent hypoxic stimulus plus surface-electrode muscle electrostimulation to increase the circulating concentrations of hematopoietic CD34+ stem cells in a group of four healthy men aged around 50 years old. This increase can be considered as substantial, because it is generally accepted that a concentration of 7 cells $/ \mu \mathrm{L}$ is equivalent to approximately $5 \cdot 10^{5} \mathrm{cells} \cdot \mathrm{kg}^{-1}$ in an adult subject. This concentration can be assumed to be useful for harvesting purposes and corresponds to a considerable fraction of the increase in $\mathrm{CD} 34^{+}$cells obtained after a standard five-day treatment involving two-day doses of G-CSF (personal data).

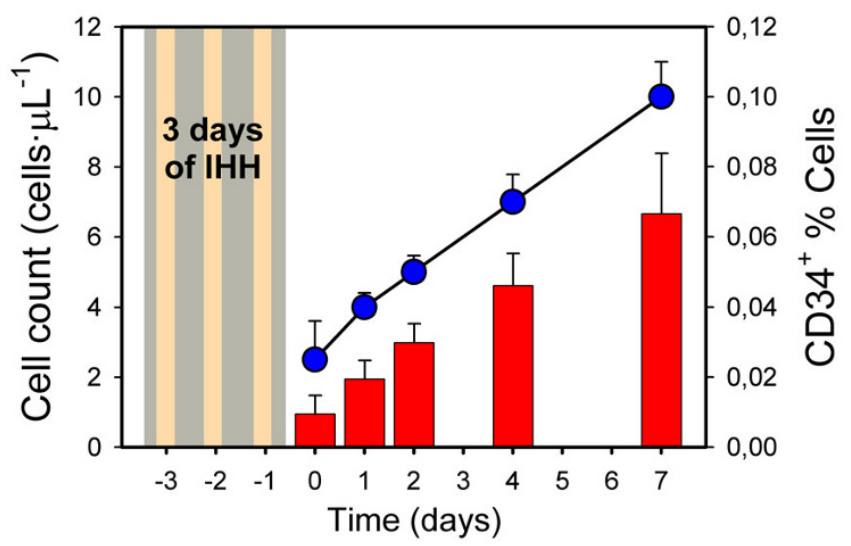

\section{Figure I}

CD34+ cells after hypobaric hypoxia and muscle electrostimulation. Evolution of the CD34+ cell count (left axis; red bars) and percentage (right axis; blue circles) during the HME experimental set. Category medians and positive standard errors are shown for the two variables. A statistically significant increase for CD34+ concentration (cells $/ \mu \mathrm{L}$ ) was found $(p=0.009)$. 
Table I: Leukocyte parameters in the three experimental sets

\begin{tabular}{|c|c|c|c|c|c|c|c|c|c|}
\hline \multirow[b]{2}{*}{ Sampling days } & & \multicolumn{3}{|c|}{ Before IHH } & \multicolumn{5}{|c|}{ After 3 days of IHH } \\
\hline & & -2 & -1 & $\mathbf{0}$ & $\mathbf{I}$ & 2 & 4 & 7 & 10 \\
\hline \multirow[t]{6}{*}{ Total leukocyte count } & $\mathrm{OH}$ & 6.4 & 7.2 & 7.1 & 6.7 & 7.6 & 7.1 & 6.6 & \\
\hline & & 1.10 & 1.25 & 1.51 & 1.53 & 1.72 & 1.30 & 1.32 & \\
\hline & HME & & & 7.2 & 7.0 & 6.8 & 6.7 & 6.9 & \\
\hline & & & & 1.93 & 2.36 & 0.54 & 1.33 & 1.31 & \\
\hline & OME & & & 6.2 & 6.9 & 7.6 & 6.9 & 8.7 & 7.8 \\
\hline & & & & 2.86 & 0.45 & 0.71 & 1.86 & 1.25 & 1.17 \\
\hline \multirow[t]{6}{*}{ \% Lymphocytes } & OH & 31.9 & 31.6 & 29.4 & 28.3 & 30.0 & 29.2 & 33.3 & \\
\hline & & 5.00 & 4.88 & 6.68 & 7.01 & 6.65 & 6.88 & 6.03 & \\
\hline & HME & & & 40.0 & 27.9 & 32.4 & 47.1 & 35.7 & \\
\hline & & & & 7.50 & 7.29 & 5.39 & 10.53 & 6.24 & \\
\hline & OME & & & 43.2 & 36.2 & 31.7 & 27.5 & 31.7 & 34.7 \\
\hline & & & & 5.40 & 2.80 & 5.61 & 7.14 & 8.88 & 6.14 \\
\hline \multirow[t]{6}{*}{$\% M N C$} & OH & 43.2 & 44.2 & 40.4 & 37.4 & 41.0 & 41.0 & 42.3 & \\
\hline & & 3.80 & 3.04 & 7.08 & 7.78 & 8.53 & 7.75 & 6.44 & \\
\hline & HME & & & 40.5 & 30.0 & 42.9 & 33.7 & 30.6 & \\
\hline & & & & 7.67 & 8.74 & 7.46 & 7.18 & 6.06 & \\
\hline & OME & & & 42.7 & 38.2 & 34.3 & 41.6 & 44.1 & 43.3 \\
\hline & & & & 4.20 & 3.02 & 5.31 & 7.40 & 10.03 & 6.71 \\
\hline \multirow[t]{6}{*}{$\%$ CD34+ } & OH & 0.081 & 0.050 & 0.064 & 0.063 & 0.061 & 0.050 & 0.075 & \\
\hline & & 0.006 & 0.040 & 0.014 & 0.017 & 0.012 & 0.026 & 0.023 & \\
\hline & HME & & & 0.025 & 0.040 & 0.050 & 0.070 & 0.100 & \\
\hline & & & & 0.017 & 0.008 & 0.019 & 0.036 & 0.030 & \\
\hline & OME & & & 0.050 & 0.040 & 0.055 & 0.035 & 0.045 & 0.045 \\
\hline & & & & 0.013 & 0.010 & 0.017 & 0.019 & 0.024 & 0.028 \\
\hline \multirow[t]{6}{*}{$\mathrm{CD} 34^{+} / \mathrm{L}$} & OH & 4.60 & 3.20 & 4.55 & 4.04 & 4.20 & 3.95 & 5.35 & \\
\hline & & 0.81 & 3.36 & 1.92 & 1.18 & 1.14 & 2.09 & 1.93 & \\
\hline & HME & & & 0.95 & 1.95 & 2.99 & 4.62 & 6.66 & \\
\hline & & & & 0.71 & 0.71 & 1.36 & 2.61 & 2.91 & \\
\hline & OME & & & 3.30 & 2.30 & 3.45 & 2.30 & 3.80 & 3.60 \\
\hline & & & & 1.06 & 0.92 & 1.46 & 2.42 & 2.09 & 2.53 \\
\hline
\end{tabular}

Data are median values and standard deviations. Total leukocyte count and subtype percentages were assessed by automatic cell counter. CD34+ absolute concentration (cells/ $\mu \mathrm{L}$ ) and percentage were obtained by flow cytometry.

It also seems that the increases in CD34+ produced by GCSF have a non-progressive tendency, as reported in a study of patients with myocardial infarction, in whom circulating $\mathrm{CD}_{34} 4^{+}$levels began to decrease the day after the fourth consecutive dose of G-CSF, reaching the previous concentrations between days 6 and 10 after the end of GCSF treatment [33]. In the present study, CD34+ levels appear to continue increasing 7 days after the last hypoxia session, and thus it is not clear if a plateau or maximum value has been reached. It should also be taken into account that G-CSF shows some pro-thrombotic effects[34,35].

The lack of response in the OHE experiment does not seem attributable to the age of the study participants, since a clear HSC response to physical exercise was detected in a group of 63-year-old men [6]. However, there are alternative explanations for these findings: 1) the relatively short duration of the hypoxic stimulus (a total of $9 \mathrm{~h}$ ), whereas positive neurogenesis in rats was demonstrated after applying a hypoxic stimulus of $4 \mathrm{~h}$ per day over two weeks [9], while other studies detected a positive SC response to physical exercise after about three months of routine physical activity $[5,6]$; at all events 7 days are enough after myocardial infarction to increase the number of $\mathrm{CD}^{2} 4^{+}$cells [36] and a single intense exercise test is able to increase HSC $24-48 \mathrm{~h}$ after an exercise bout $[37,38]$; or 2$)$ the low intensity of the stimulus in our study (used in order to be applied and tolerable to a large majority of healthy people) compared with some in vitro studies, in which clearly more hypoxic atmospheres were used $[10,11]$. Obviously, a higher number of repeated hypoxia sessions could be applied; however, it does not seem reasonable to use much more intense (higher simu- 
lated altitude) or longer hypoxic sessions as these might not be tolerated by some people or patients.

It is also worth noting some of the advantages of muscular electrostimulation over exercise during hypoxia exposure: a) it is easy to measure and reproduce; b) it can be applied in a hypoxic atmosphere (hypobaric chamber or breathing a hypoxic mixture); and c) it can be applied to the majority of humans, even those with mild or severe physical limitations for standard exercise. It is not clear from the present study whether muscular electrostimulation should necessarily be applied simultaneously during hypoxia exposure.

The major limitations of the present study are the short total duration of the hypoxic stimulus in OHE (which was sufficient in HME) and the small sample size; however, given the results it does not seem very likely that a larger sample size would produce significant differences. The lack of a more complete hematologic study means we cannot rule out the possibility that the $\mathrm{CD} 34^{+}$increase is caused by a decrease in "homing" mechanisms in possible target tissues, although this does not seem a likely phenomenon in this case.

Regrettably, our protocol is unable to determine the optimal stimulation timing in order to produce a stable increase in $\mathrm{CD}_{3} 4^{+}$cells, although the apparent maintained effect observed (CD34+ increasing 7 days after the stimulus) suggests that some repeated "doses" might alone be enough.

Further studies are required to address several questions derived from the present research: a) the potential repercussions of the detected CD34+ increase on different pathologies, it perhaps being possible to increase HSC homing in injured tissues because after the release of HSCs from bone marrow, cells home to ischemic or damaged regions via alterations of the affected tissue [39]; b) determining the most efficient protocols to induce an optimal and maintained increase in HSC; c) the possibility that the $\mathrm{OH}$ or OME stimulus applied via more persistent schedules might also induce a measurable increase in HSC; and d) the need for a more exhaustive study of the possible subclasses of SC released under HME conditions.

\section{Conclusion}

1) A simple protocol stimulating healthy humans with hypoxia plus muscle electrostimulation can quickly induce a notable increase in blood HSC.

2) The significant differences obtained in the HME experimental set over such a short period of time, coupled with the easy application of these two combined stimuli, make this method an interesting tool to increase efficiency in peripheral HSC collection.

\section{Competing interests}

This study has been performed without support form any public or private fund, agency or company. The authors declare that they have no competing interests.

\section{Authors' contributions}

GV: conception and design of the study, experimental subject, collection and/or assembly of data, data analysis and interpretation, manuscript writing, final approval of manuscript; CJ: conception and design of the study, experimental subject, collection and/or assembly of data, data analysis and interpretation, manuscript writing; TP: conception and design of the study, collection and/or assembly of data, data analysis and interpretation, manuscript writing; JLV: conception and design of the study, experimental subject, collection and/or assembly of data, data analysis and interpretation, manuscript writing; AR: conception and design of the study, experimental subject, collection and/or assembly of data, data analysis and interpretation, manuscript writing; GMH: collection and/ or assembly of data, data analysis and interpretation, manuscript writing; CA: collection and/or assembly of data, data analysis and interpretation, manuscript writing; RS: data analysis and interpretation, manuscript writing. All authors read and approved the final manuscript.

\section{Additional material}

\section{Additional file 1}

GV and CJ during HME protocol. The intensity of muscle electrostimulation can be observed in this short movie.

Click here for file

[http://www.biomedcentral.com/content/supplementary/14795876-7-91-S1.mov]

\section{Additional file 2}

CHEx-1 Hypobaric chamber. The hypobaric chamber into BioPol facility at University of Barcelona Campus Bellvitge.

Click here for file

[http://www.biomedcentral.com/content/supplementary/14795876-7-91-S2.jpeg]

\section{Acknowledgements}

The authors are grateful to Mr. Víctor Gómez by his kind support to our research group and by his critical participation in the installation of the hypobaric chamber and annexed facilities. We are also grateful to Mr. Juan A. Silva from Universidad de Antofagasta (Chile) by his collaboration in some data collection, and to Mr. Robin Rycroft (Language Advice Service, Universitat de Barcelona) for his useful help in editing the manuscript.

\section{References}

I. Asahara T, Murohara T, Sullivan A, Silver M, Zee R van der, Li T, Witzenbichler B, Schatteman G, Isner JM: Isolation of putative progenitor endothelial cells for angiogenesis. Science (New York, $N$ Y) 1997, 275:964-967.

2. Ferrario M, Massa M, Rosti $\bigvee$, Campanelli R, Ferlini M, Marinoni B, De Ferrari GM, Meli V, De Amici M, Repetto A, Verri A, Bramucci E, 
Tavazzi L: Early haemoglobin-independent increase of plasma erythropoietin levels in patients with acute myocardial infarction. Eur Heart J 2007, 28: |805-1813.

3. Theiss HD, David R, Engelmann MG, Barth A, Schotten K, Naebauer M, Reichart B, Steinbeck G, Franz WM: Circulation of CD34+ progenitor cell populations in patients with idiopathic dilated and ischaemic cardiomyopathy (DCM and ICM). Eur Heart J 2007, 28: 1258-1264.

4. Roberts N, Xiao Q, Weir G, Xu Q, Jahangiri M: Endothelial Progenitor Cells are Mobilized After Cardiac Surgery. Ann Thorac Surg 2007, 83:598-605.

5. Steiner S, Niessner A, Ziegler S, Richter B, Seidinger D, Pleiner J, Penka M, Wolzt M, Huber K, Wojta J, Minar E, Kopp CW: Endurance training increases the number of endothelial progenitor cells in patients with cardiovascular risk and coronary artery disease. Atherosclerosis 2005, 181:305-310.

6. Hoetzer GL, Van Guilder GP, Irmiger HM, Keith RS, Stauffer BL, DeSouza CA: Aging, exercise, and endothelial progenitor cell clonogenic and migratory capacity in men. J Appl Physiol 2007, 102:847-852.

7. Meng X, Ichim T, Zhong J, Rogers A, Yin Z, Jackson J, Wang H, Ge W, Bogin V, Chan K, Thebaud B, Riordan N: Endometrial regenerative cells: A novel stem cell population. Journal of Translational Medicine 2007, 5:57.

8. Kondo T, Hayashi M, Takeshita K, Numaguchi Y, Kobayashi K, lino S, Inden Y, Murohara T: Smoking cessation rapidly increases circulating progenitor cells in peripheral blood in chronic smokers. Arterioscler Thromb Vasc Biol 2004, 24: I 442-1447.

9. Zhu LI, Zhao T, Li Hs, Zhao H, Wu Ly, Ding As, Fan Wh, Fan M: Neurogenesis in the adult rat brain after intermittent hypoxia. Brain Res 2005, 1055: I-6.

10. Qiang Xu, Penka M, Wolzt M, Huber K, Wojta J, Minar E, Kopp CW: Hypoxia-Induced Astrocytes Promote the Migration of Neural Progenitor Cells Via Vascular Endothelial Factor, Stem Cell Factor, Stromal-Derived Factor-Ialpha and Monocyte Chemoattractant Protein-I Upregulation in Vitro. Clin Exp Pharmacol Physiol 2007, 34:624-63I.

II. Grayson W, Zhao F, Bunnell B, Ma T: Hypoxia enhances proliferation and tissue formation of human mesenchymal stem cells. Biochem Biophys Res Commun 2007, 358:948-953.

12. Flames N, Pla R, Gelman DM, Rubenstein JLR, Puelles L, Marin O: Delineation of Multiple Subpallial Progenitor Domains by the Combinatorial Expression of Transcriptional Codes. J Neurosci 2007, 27:9682-9695.

13. Werner N, Kosiol S, Schiegl T, Ahlers P, Walenta K, Link A, Böhm M, Nickenig G: Circulating Endothelial Progenitor Cells and Cardiovascular Outcomes. N Engl J Med 2005, 353:999-1007.

14. Miller-Kasprzak E, Jagodzinski PP: Endothelial progenitor cells as a new agent contributing to vascular repair. Arch Immunol Ther Exp (Warsz) 2007, 55:247-259.

15. Stamm C, Westphal B, Kleine HD, Petzsch M, Kittner C, Klinge H, Schümichen C, Nienaber CA, Freund M, Steinhoff G: Autologous bone-marrow stem-cell transplantation for myocardial regeneration. Lancet 2003, 361:45-46.

16. Perin EC, Dohmann HF, Borojevic R, Silva SA, Sousa AL, Mesquita CT, Rossi MI, Carvalho AC, Dutra HS, Dohmann HJ, Silva GV, Belém L, Vivacqua R, Rangel FO, Esporcatte R, Geng YJ, Vaughn WK, Assad JA, Mesquita ET, Willerson JT: Transendocardial, autologous bone marrow cell transplantation for severe, chronic ischemic heart failure. Circulation 2003, 107:2294-2302.

17. Cashen AF, Lazarus HM, Devine SM: Mobilizing stem cells from normal donors: is it possible to improve upon G-CSF? Bone Marrow Transplant 2007, 39:577-588.

18. Assmus B, Schachinger V, Teupe C, Britten M, Lehmann R, Dobert N, Grünwald F, Aicher A, Urbich C, Martin H, Hoelzer D, Dimmeler S, Zeiher AM: Transplantation of Progenitor Cells and Regeneration Enhancement in Acute Myocardial Infarction (TOPCARE-AMI). Circulation 2002, 106:3009-3017.

19. Valina C, Pinkernell K, Song YH, Bai X, Sadat S, Campeau RJ, Le Jemtel TH, Alt E: Intracoronary administration of autologous adipose tissue-derived stem cells improves left ventricular function, perfusion, and remodelling after acute myocardial infarction. Eur Heart J 2007, 28:2667-2677.

20. Bahlmann FH, de Groot K, Spandau JM, Landry AL, Hertel B, Duckert T, Boehm SM, Menne J, Haller H, Fliser D: Erythropoietin regulates endothelial progenitor cells. Blood 2004, 103:921-926.
21. Westenbrink BD, Lipsic E, Meer P van der, Harst P van der, Oeseburg H, Du Marchie Sarvaas GJ, Koster J, Voors AA, van Veldhuisen DJ, van Gilst WH, Schoemaker RG: Erythropoietin improves cardiac function through endothelial progenitor cell and vascular endothelial growth factor mediated neovascularization. Eur Heart J 2007, 28:2018-2027.

22. Serebrovskaya TV: Intermittent hypoxia research in the former Soviet Union and the Commonwealth of independent states: History and review of the concept and selected applications. High Alt Med Biol 2002, 3:205-22I.

23. Levine BD: Intermittent Hypoxic Training: Fact and Fancy. High Alt Med Biol 2002, 3:177-193.

24. Levine BD, Stray-Gundersen J: "Living high-training low": effect of moderate-altitude acclimatization with low-altitude training on performance. J Appl Physiol I997, 83: I02-I I2.

25. Koutedakis Y, Frischknecht R, Vrbova G, Sharp NC, Budgett R: Maximal voluntary quadriceps strength patterns in Olympic overtrained athletes. Med Sci Sports Exerc 1995, 27:566-572.

26. Crameri RM, Weston A, Climstein M, Davis GM, Sutton JR: Effects of electrical stimulation-induced leg training on skeletal muscle adaptability in spinal cord injury. Scand J Med Sci Sports 2002, 12:316-322.

27. Brocherie F, Babault N, Cometti G, Maffiuletti N, Chatard JC: Electrostimulation training effects on the physical performance of ice hockey players. Med Sci Sports Exerc 2005, 37:455-460.

28. Panisello P, Torrella JR, Pages T, Viscor G: Capillary Supply and Fiber Morphometry in Rat Myocardium after Intermittent Exposure to Hypobaric Hypoxia. High Alt Med Biol 2007, 8:322-330.

29. Panisello P, Torrella JR, Esteva S, Pages T, Viscor G: Capillary supply, fibre types and fibre morphometry in rat tibialis anterior and diaphragm muscles after intermittent exposure to hypobaric hypoxia. Eur J Appl Physiol 2008, 103:203-213.

30. Rodriguez FA, Ventura JL, Casas M, Casas H, Pages T, Rama R, Ricart A, Palacios L, Viscor G: Erythropoietin acute reaction and haematological adaptations to short, intermittent hypobaric hypoxia. Eur J Appl Physiol 2000, 82: I70-177.

31. Bennie SD, Petrofsky JS, Nisperos J, Tsurudome M, Laymon M: Toward the optimal waveform for electrical stimulation of human muscle. Eur J Appl Physiol 2002, 88:13-19.

32. Keeney M, Chin-Yee I, Weir K, Popma J, Nayar R, Sutherland DR: Single platform flow cytometric absolute CD34+ cell counts based on the ISHAGE guidelines. International Society of Hematotherapy and Graft Engineering. Cytometry 1998, 34:6I-70.

33. Valgimigli M, Rigolin GM, Cittanti C, Malagutti P, Curello S, Percoco G, Bugli AM, Della Porta M, Bragotti LZ, Ansani L, Mauro E, Lanfranchi A, Giganti M, Feggi L, Castoldi G, Ferrari R: Use of granulocyte-colony stimulating factor during acute myocardial infarction to enhance bone marrow stem cell mobilization in humans: clinical and angiographic safety profile. Eur Heart $J$ 2005, 26: 1838-1845.

34. Falanga A, Marchetti M, Evangelista V, Manarini S, Oldani E, Giovanelli S, Galbusera M, Cerletti C, Barbui T: Neutrophil activation and hemostatic changes in healthy donors receiving granulocyte colony-stimulating factor. Blood 1999, 93:2506-25।4.

35. Gutierrez-Delgado F, Bensinger W: Safety of granulocyte colonystimulating factor in normal donors. Curr Opin Hematol 200I. 8: $155-160$.

36. Shintani S, Murohara T, lkeda H, Ueno T, Honma T, Katoh A, Sasaki K, Shimada T, Oike Y, Imaizumi T: Mobilization of endothelial progenitor cells in patients with acute myocardial infarction. Circulation 200I, 103:2776-2779.

37. Adams V, Lenk K, Linke A, Lenz D, Erbs S, Sandri M, Tarnok A, Gielen $S$, Emmrich F, Schuler G, Hambrecht R: Increase of circulating endothelial progenitor cells in patients with coronary artery disease after exercise-induced ischemia. Arterioscler Thromb Vasc Biol 2004, 24:684-690.

38. Laufs U, Urhausen A, Werner N, Scharhag J, Heitz A, Kissner G, Böhm M, Kindermann W, Nickenig G: Running exercise of different duration and intensity: effect on endothelial progenitor cells in healthy subjects. Eur J Cardiovasc Prev Rehabil 2005, I 2:407-4|4.

39. Wahl P, Brixius K, Bloch W: Exercise-induced stem cell activation and its implication for cardiovascular and skeletal muscle regeneration. Minim Invasive Ther Allied Technol 2008, 17:91-99. 